\title{
Influence of School Environment on Vocational Interest among Adolescents
}

\author{
Dr. Karuna Sharma \\ Department of Home Science, University of Rajasthan, Jaipur; India
}

\begin{abstract}
For adolescent their vocational choice is one channel through which their life's goal and purpose might be fulfilled. Career has been defined as the total pattern of one's activities held during a person's life-time (Natalie, 2006).The career choice that adolescents make is a decision that is influenced not only by their development but also by the context in which they live (Chen, 1997).School environment is a powerful force and plays pivotal role in the all-round development, of the child. Children in the developed world spend many hours in schools. School environment influences on vocational interest appeared to be a relatively new area of investigation. This research primarily focused on the role of teachers, classmates, peers' influence, or the interaction between teachers and children in vocational choice. Research indicates that schools are active agents in influencing their children's career development. This study is going to review the influence of this inevitable factor. The purpose of this chapter is to summarize the literature on influence of school environment on vocational interest among adolescents.
\end{abstract}

Keywords: School environment, Vocational Interest, Adolescent, Career choice

\section{Introduction}

Adolescents in India are estimated to be 230 million and will play a major role in determining the size and growth pattern of India's population (Saldanha, 2007).Career is a lifelong experience, which enables individuals to earn money or to get all his or her needs provided(Fabea\&Bossman, 2014).Career development, for most people, is a lifelong process of engaging the work world through choosing among employment opportunities made available to them. Each individual undertaking the process is influenced by many factors, including the context in which they live, their personal aptitudes, and educational attainment (Bandura, Barbaranelli, Caprara, \&Pastorelli, 2001).

Initial career decision-making is a cultural, developmental task that adolescents are expected to have accomplished by the end of their high school year (Super, Savicks, \& Super, 1996).Unlike the informal world of peer relations, the school is a formal institution designed to transmit the knowledge and skills, children need to become productive members of society (Berk, 2007). Youth in communities of more affluence appeared to have more family and school support in career exploration, which resulted in consideration of a wider range of career options (Natalie, 2006). According to Sager and Kaplan (1972) next to family, the school is the most important experience in the process of child development.A major turning point in adolescents' lives involves the career choice that they make while in high school. (Ferry, 2006). High school is the main settings in which adolescents spend time away from home. It is a larger, complex institution with a variety of educational and socialization goals, these are not the elements of the high school that seem to make the deepest impressions on young adolescents (Newman \& Newman, 1986).

The school as an influential source of learning in the career development of children.Jablin (1985) suggested that school is often children's first formal introduction to nonparent hierarchies and permits them the opportunity to observe and participate inorganized activities with others. Furthermore, school offers children and adolescents the opportunity to learn how people communicate in different occupational or organizational roles by observing interactions involving students, teachers, the principal, and others.Schools are also becoming more involved in the job-selection process, easingadolescents to identify jobs with stronger learning potential (Stone \& Mortimer, 1998).

A study (McMahon et al., 2001) found that school was one of a number of influences on career information. The final school years are critical in the career decision-making process, as this is when students typically begin to plan, explore and make decisions about employment (Rogers, Creed \&Glendon 2008). The school plays a role in vocational interest. Colleges are characterized by a "new vocationalism" or focus or practicality (Rice, 1996).Vondracek et al. (1986) stated that it is through the school that the child is provided with his or her first structured social arena with which to encounter and realize the consequences of social and academic competence, competition and power relationships, which may be extremely important in career development.

Schools and parents are theorized to play important roles in career development from more traditional (Nurmi, 1991; Super, 1980) and emanicipatory communication perspectives (Blustein et al., 2005). The seminal „Career Pattern Studye (Super, 1985) andthe status attainment tradition in sociology (Sewell \& Hauser, 1975) suggest that parental and school factors influence the career development and occupational attainment of young adults. Constantine et al. (1998) and Solberg et al. (2002) argued that parental and school support facilitates career development; this notion has been supported by various research (Constantine,Wallace, \&Kindaichi, 2005; Kenny, Blustein, Chaves, Grossman, \& Gallagher, 2003; Sirin et al., 2004; Turner \&Lapan, 2002).

\section{Teachers}

Teachers, school counsellors, and peer values also affect adolescent's choices.Vocational interests of the adolescents 


\section{International Journal of Science and Research (IJSR) \\ ISSN (Online): 2319-7064 \\ Index Copernicus Value (2013): 6.14 | Impact Factor (2014): 5.611}

at school rest on teachers and counsellors (Denga 1998). School counsellors also provide advice and assistance in career development, especially for young people who plan to attend college (Feller, 1996; Hughey\&Hughey, 1999). Teachers may play a particularly important role in influencing the career choice (Dick and Rallis 1991).Johnson (1967) showed a significant influence, that school personnel exert on vocational choice of students. School personnel and Adult friends exert significant influence over vocational interest of students (Saltied, 1986).Ebenehiet. al (2015), concluded that students need innovative vocational educators, career counselors, and the managers to activate the adaptability skill potentials in them.In the school, good teacher/students relationship, availability of guidance counsellors, organized career talk, seminar, workshop, and accurate vocational information, would affect vocational interest (Balogun, 2006). Johnson (2004) in Kumasi Ghana, also studied determiners of career choice of students, with a sample size of 300 , he concluded from his studies that school personnel influences are more pronounced on students in the boarding school. This is because the boarders have a much closer rapport with teachers than other students. Dick and Rallis (1991) examined 2,000 high school students in the United States of America, and found that teachers had a strong influence on girlse $^{\text {ce }}$ choices of career in mathematics. Teacher or counsellor advising tends to reflect a gender bias when directing girls towards traditional careers and boys to nontraditional careers (Gates, 2002). Women in Information Technology (IT) are most discouraged by teachers, guidance counsellors, and male professors (Turner, 2002), although women who moved from non-IT to IT careers often indicated male professors to be a strong influence in that move (Canes \& Rosen, 1995).

\section{School Education}

Jablin (2000) suggested that the information that students receive from their educational institutions is more often about general requirements of jobs than specific career options.Melgosa (1987) studied that proper vocational education will train students to better vocational choice.Several authors call for the implementation of school programs/career education (Gregg and Dobson, 1980; Hoffman and McDaniels, 1991; Jordan, 1976; McMahon et al., 2001) as a source of learning realistic occupational information, challenging occupational gender stereotypes, and educating parents in their role in children"s career development (Wahl and Blackhurst, 2000).Moro, (2000) indicated that high school teachers and the programmes read at the senior high school had been most influential in their decision influences their career choice.Some studies report on specific career education interventions, others have examined the influence of school on children's career development.

\section{Discussion}

The environment may influence adolescents negatively or positively. When the environments of the home, school and society is conducive for the adolescents, theydevelop high, positive and healthy self-concept (Okereke, 2006). The interdependence of school, and community culture played a critical role in shaping the youth's occupational choice.High schools, a wide range of difference existed in career choice (Ferry, 2006).It was found from the study that the teachers, educational factor influence the career choice of the children.

\section{Suggestions}

Below are some suggestions to some major participantssuch as parents, students and counsellors-(1. Career choice should be inculcated in the school curriculum so that right from the start students would know what should go into their choice of careers. (2. Education should be vocationalised so that student will adjust better to work atmosphere when they are employed. (3. Schools should emphasized more on vocational training programmes. (4. Counselling bureaus should be opened in each schools and colleges. (5. Teachers and parents should encouraged the children towards the choice of vocation and the students should be motivated to take the initiative to gather information on vocational field that they are interested in, this will improve their ability to take decisions about future career. (6. Child magazine that deals with occupational and educational opportunities should be published. (7. As part of the school curriculum, children should be allowed to speak to their classmate on vocational choices and interests.

\section{Implication of the Study}

The study will be useful to the administrators, policy makers, for making reforms in the education system. It will be useful to the school and psychological counselors for the effective counseling of adolescents and their parents regarding career counselling and self-growth. It can be used by parents, teachers and administrations at individual level and at group level in exposing adolescents towards various career options.

\section{References}

[1] Bandura, A., Barbaranelli, C., Caprara, G.V., \&Pastorelli, C. (2001). Self-efficacy beliefs as shapers of children's aspirations and career trajectories. Child Development, 72, 187-206

[2] Berk, L. E. (2007). Peers, media, and schooling. Child Development. ( $7^{\text {th }}$ ed.). Pearson Prentice Hall.

[3] Blustein, D. L., McWhirter, E. H., \& Perry, J. C. (2005). An emancipatory communitarian approach to vocational development: Theory, research, and practice. The Counseling Psychologist, 33, 141-179

[4] Balogun, (2006). Career Prospects in Vocation and Technical Education. In Joseph Ado (Ed), Magazine of the 30th Annual National Conference of the Counselling Association of Nigeria 1(1), 45-49

[5] Canes, Y., \& Rosen, W. (1995). Engineering education for primary school students. New York: Random House.

[6] Chen, C.P. (1997). Career projection: Narrative in context. Journal of Vocational Behavior, 54, 279-295.

[7] Constantine, M., Erickson, C. D., Banks, R. W., \& Timberlake, T. L. (1998). Challenges to the career development of urban racial and ethnic minority youth: Implications for vocational intervention. Journal of Multicultural Counseling \& Development, 26(2), 82-95. 


\section{International Journal of Science and Research (IJSR) \\ ISSN (Online): 2319-7064}

Index Copernicus Value (2013): 6.14 | Impact Factor (2014): 5.611

[8] Constantine, M. G., Wallace, B. C., \&Kindaichi, M. M. (2005). Examining contextual factors in the career decision status of African American Adolescents. Journal of Career Assessment, 13(3), 307-319

[9] Denga, D. (1998). Effects of Counselling on Development of Children Self Concept: A pilot study. The Journal of Education in Africa 2: (1): 110-118

[10]Dick, T. P. \& Rallis, S. F. (1991). Factors and Influences on High School Students' Career Choices. Journal for Research in Mathematics Education, 22(4), 281-292.

[11]Ebenehi, A. S., Rashid, A.M., Rahim, B. A., \&Asimiran, S. (2015). Vocational Identity Statutes and Career Adaptability Skill among Technical and Vocational Education Students in Nigeria.The International Journal of Science \&Technoledge, 3(12), $146-151$

[12] Ferry, N. M. (2006). Factors Influencing Career Choices of Adolescents and Young Adults in Rural Pennsylvania. Extension Journal,44(3), Research in Brief // 3RIB7

[13]Fabea\&Bossman, I. (2014). Educational factors that influence the career choices of university of Cape Coast students. International Journal of Research In Social Sciences, 4(2), 40-49.

[14]Feller, R. W. (1996). Redefining "career" during the work revolution. In R. Feller \& G. walz (Eds.), Career transitions in turbulent times: Exploring work, learning and careers (pp.143-154).

[15] Gates, R. (2002). Sociological methods. New York: McGraw-Hill.

[16] Gregg, C. H., \& Dobson, K. (1980). Occupational sex role stereotyping and occupational interests in children. Elementary School Guidance and Counselling, 15, 6675.

[17]Hoffman, L. R., \&McDaniels, C. (1991). Career development in the elementary schools: A perspective for the 1990s. Elementary School Guidance and Counselling, 25, 163-171.

[18] Hughey, K. F., \&Hughey, J. K. (1999). Preparing students for the future: Making career development a priority. Journal of Career Development, 25, 203-216.

[19] Jablin, F. M. (1985). An exploratory study of vocational organizational socialization. Southern Speech Communication Journal, 50, 261-282.

[20] Jablin, F. M. (2000). Organizational entry, assimilation, and disengagement/exit. In F. M. Jablin\& L. L. Putman (Eds.). The handbook of organizational communication (pp.732-818). Thousand Oaks, CA: Sage.

[21] Johnson, E. G. (1967). The Impact of High School Teachers on the Educational Plans Of College Freshmen. Testing and Counselling Service Report No. 32 Orono: University of Maine mimeo.

[22] Johnson, M. (2004). An investigation of the willingness of managerial employees to accept an expatriate assignment. Journal of Organizational Behaviour, 17, 267-284.

[23]Jordan, T. E. (1976). Preschool influences on occupational knowledge of seven-year-olds: A prospective study. Journal of Experimental Education, 44, 27-37.

[24] Kenny, M. E., Blustein, D. L., Chaves, A., Grossman, J. M., \& Gallagher, L. A. (2003). The role of perceived barriers and relational support in the educational and vocational lives of urban high school students. Journal of Counselling Psychology, 50(2), 142-155.

[25] McMahon, M., Carroll, J., \& Gillies, R. M. (2001). Career dreams: Occupational aspirations of year six children. Australian Journal of Career Development, $10,25-31$.

[26] Melgosa, J. (1987). Development and Validation of the Occupational Identity Scale. Journal of Adolescents, 10, 385-397.

[27]Moro, M. (2000). A journey worth traveling: Globalisation of counseling psychology. The Counseling Psychologist, 31, 412-419

[28] Natalie, M. (2006). Factors influencing career choice among high school students in Tanzania. Journal of Dental Education, 64 (6) 423-429.

[29] Newman, B. M. \& Newman, P. R. (1986). Adolescent development. U.S.A., Merrill Publishing Company.

[30] Nurmi, J. E. (1991). How do adolescents see their future? A review of the development of future orientation and planning. Developmental Review, 11(1), $1-59$.

[31] Okereke, C.P. (2006). Patterns of Career Salience and Role Model among Adolescent Students. Unpublished M.Ed Research, Abia State University, Uturu.

[32]Rice, F. P. (1996). The adolescent development, relationships and culture. $\left(8^{\text {th }}\right.$ ed.). U.S.A., Allyn\& Bacon.

[33] Rogers, M. E., Creed, P. A., \&Glendon, A. I. (2008). The role of personality in adolescent career planning and exploration: A social cognitive perspective. Journal of Vocational Behaviour, 73, 132-142

[34] Sager, \& Kaplan, B. J. (1972). Malnutrition and mental deficiency. Psychological Bulletin, 78.

[35] Saldanha, D. (2007). Education of adolescents: for development in India. Jaipur Rawat publications.

[36] Saltiel, J. (1996), "Segmental Influence: The case of educational and occupational significant others: Adolescence ", 21, 615-622

[37] Sirin, S. R., Diemer, M. A., Jackson, L. R., Gonsalves, L., \& Howell, A. (2004). Future aspirations of urban adolescents: A person-in-context model. Qualitative Studies in Education, 17(3), 437-460.

[38] Solberg, V. S., Howard, K. A., Blustein, D. L., \& Close, W. (2002). Career development in the schools: Connecting school-to-work-to-life. The Counseling Psychologist, 30, 705-725.

[39] Super, D. E. (1980). A life-span, life-space approach to career development. Journal of Vocational Behaviour, 16, 262-298.

[40] Super, D. E. (1985). Coming of age in Middletown: Careers in the making. American Psychologist, 40, 405411.

[41] Super, D.E., Savickas, M.L., \& Super, C.M. (1996). The life-span approach to careers. In D. Brown, L. Brooks, \& Associates (Eds.) Career choice and development (pp. 121-178). San Francisco: Jossey-Bass.

[42] Stone, J. R., \& Mortimer, J. T. (1998). The effect of adolescent employment on vocational development: Public and educational policy implications. Journal of Vocational Behavior, 53, 184-214. 


\section{International Journal of Science and Research (IJSR) \\ ISSN (Online): 2319-7064}

Index Copernicus Value (2013): 6.14 | Impact Factor (2014): 5.611

[43] Sewell, W. H., \& Hauser, R. M. (1975). Education, occupation, and earnings: Achievement in early career. New York: Academic Press.

[44] Turner, M. (2002). Organizational entry: Recruitment, selection, orientation and socialization of newcomers. MA: AddisonWesley

[45] Turner, S., \&Lapan, R. T. (2002). Career self-efficacy and perceptions of parental support in adolescent career development. Career Development Quarterly, 51(1), 44-55.

[46] Vondracek, F. W., Lerner, R. M., \&Schulenberg, J. E. (1986). Career development: A life-span developmental approach. Hillsdale, NJ: Lawrence Erlbaum.

[47] Wahl, K. H., \&Blackhurst, A. (2000). Factors affecting the occupational and educational aspirations of children and adolescents. Professional School Counselling, 3, $367-374$. 